\section{Kandungan Protein dan Kadar Air Bakso Daging Ayam Broiler pada Penambahan Bahan Pengenyal yang Berbeda}

\author{
Rusli \\ Intan Dwi Novieta \\ Rasbawati
}

\begin{abstract}
Abstrak. Penelitian bertujuan untuk mengetahui pengaruh penambahan pengenyal bakso yang berbeda terhadap protein bakso dan untuk mengetahui pengaruh penambahan pengenyal bakso yang berbeda terhadap kadar air bakso. Penelitian telah dilaksanankan pada bulan Juni 2018 di Laboratorium Fakultas Pertanian, Peternakan, dan Perikanan Universitas Muhammadiyah Parepare. Penelitian menggunakan daging ayam broiler, air, penyedap rasa, bawang putih, merica, garam, putih telur, karagenan, agar-agar, tissu, dan es batu. Penelitian menggunakan Rancangan Acak Lengkap (RAL) dengan empat taraf perlakuan dan tiga kali ulangan, yaitu $\mathrm{T}_{0}=$ Tanpa bahan pengenyal, $\mathrm{T}_{1}=$ Pengenyal putih telur, $\mathrm{T}_{2}=$ Pengenyal karagenan, $\mathrm{T}_{3}=$ Pengenyal agar-agar. Hasil penelitian menunjukkan dengan penambahan bahan pengenyal yang berbeda bahwa kandungan protein pada bakso berpengaruh sangat nyata dan kandungan kadar air pada bakso dengan penambahan bahan pengenyal yang berbeda berpengaruh nyata terhadap kadar air bakso. Rata-rata nilai protein tertinggi ke terendah adalah $\mathrm{T}_{0}$ sebesar $(6,52), \mathrm{T}_{2}$ sebesar $(6,46), \mathrm{T}_{1}$ sebesar $(6,33)$, dan $\mathrm{T}_{3}$ sebesar $(4,15)$. Rata-rata nilai kadar air tertinggi ke terendah adalah $\mathrm{T}_{1}$ sebesar $(63,35), \mathrm{T}_{0}$ sebesar $(63,05), T_{3}$ sebesar $(62,58)$, dan $T_{2}$ sebesar $(62,44)$. Dari hasil penelitian maka diketahui bahwa perlakuan terbaik dan dapat direkomendasikan yaitu perlakuan $\mathrm{T}_{2}$ dengan pengenyal karagenan.

Kata kunci: Protein, Kadar air, Daging ayam brolier, Putih telur, Karagenan, dan Agar-agar.
\end{abstract}

\section{Pendahuluan}

Daging adalah jaringan otot dari hewan yang berbentuk serat-serat otot yang panjang dan tipis yang di ikat menjadi satu oleh lapisan tipis dari jaringan ikat yang menyambung antara satu dan yang lain. Daging merupakan bahan pangan sumber protein berkualitas tinggi karna mengandung asam amino esensial, juga sebagai sumber vitamin B komplek dan kandungan vitamin-vitamin yang larut dalam lemak yaitu A,D,E,K. Dalam setiap 100 gram daging sapi mengandung kalori 207 kkal,protein 18,8 gram, lemak 14 gram,kalsium 11 $\mathrm{mg}$, besi $2,8 \mathrm{mg}$, dan vit A $30 \mathrm{mg}$ dan vit B 0,08 $\mathrm{mg}$ (DKBM, 2005). Daging ayam merupakan salah satu daging yang memegang peran yang cukup penting dalam pemenuhan kebutuhan gizi masyarakat, karena banyak mengandung protein dan zat-zat lainya seperti lemak, mineral, vitamin yang penting untuk kelancaran proses metabolisme dalam tubuh. Ayam broiler merupakan salah satu ternak penghasil daging yang cukup potensial untuk memenuhi kebutuhan masyarakat asal protein hewani. Daging broiler mengandung protein yang cukup tinggi $20-30 \%$ dan lemak yang rendah 5-0\%. Sedangkan daging sapi mengandunng protein $27-31 \%$ dan lemak 0$11 \%$. Daging ayam merupakan sumber pangan yang memiliki kandungan yang sangat lengkap yaitu sumber

\section{BIONATURE}

p-ISSN 1411 - 4720
e-ISSN 2654 - 5160

Abtract. The study aimed to determine the effect of different meatball enhancers on meatbel protein and to determine the effect of different meatball enhancers against meatball water content. This research was conducted in june 2018 at the Laboratory of the Faculty of Agriculture, Animal Husbandry and Fisheries of the University of Muhammadiyah Parepare. Research using broiler chicken meat, water flavorings, garlic, pepper, salt, egg white, carrageenan, gelatin, tissue, and ice cubes. The study used a completely randomized design (CRD) with four treatment levels and three replications, namely $\mathrm{T} 0=$ without ingreadients, $T 1=$

crisp egg white, $T 2=$ crustacean, $T=$ gelatin. The results of the study showed that with the addition of pulses that the protein content of meatballs had a very real effect and water content in meatball with the addition of different ingredients that are influential real to meatbal water content. The highest average protein value to the lowest is T0 is 6.52, $T 2$ is 6.46, T1 is 6.33, T3 is 4,15. The highest average water volues to the lowest were $\mathrm{T1}$ at 63.35, T0 at 63.05, T3 at 62.58 , and $T 2$ at 62.44 . From the

results of the study, it is known that the best treatment and can be recommended is $T 2$ treatment with karagenan crusher.

Keywords: Proteins, water content broiler chicken meat, egg white, carrageenan, and gelatin

Rusli

Universitas Muhammadiyah Parepare Indonesia

Intan Dwi Novieta

Universitas Muhammadiyah Parepare Indonesia

Rasbawati

Universitas Muhammadiyah Parepare Indonesia 
asam amino esensial yang diperlukan tubuh manusia, sehingga baik untuk dikonsumsi (Fadilah et al., 2007).

Selain nilai gizi yang lengkap daging ayam mudah didapat dengan harga yang relatif murah daripada daging sapi. Ayam broiler dapat dipanen pada umur lima sampai enam minggu dengan bobot 1,7 sampai 2 kg sehingga produksi dagingnya cepat (Peni dan Rukmiasih, 2000).

Menurut Priyatno (2003) konsumsi daging ayam meningkat paling pesat dibanding dengan daging sapi maupun kambing.Beberapa alasan yang menyebabkan kebutuhan daging ayam mengalami peningkatan yang cukup pesat antara lain: 1) Daging ayam harganya relatif murah, 2) daging ayam lebih baik dari segi keshatan karena mengandung sedikit lemak dan kaya protein dibanding daging sapi,dan kambing, 3) tidak ada agama apapun yang melarang ummatnya untuk mengonsumsi daging ayam, 4) daging ayam mempunyai rasa yang dapat diterima semua golongan masyarakat dan semua umur, 5) daing ayam cukup mudah diolah menjadi produk olahan yang bernilai tinggi, mudah disimpan dan mudah dikonsumsi.

Kebutuhan daging ayam sebagai sumber protein hewani mengalami peningkatan seiring dengan meningkatnya penghasilan dan kesadaran masyarakat akan pentingnya makanan bergizi. Usaha peternakan ayam broiler dapat dengan cepat memenuhi kebutuhan masyarakat akan protein hewani karena pertumbuhan ayam broiler relatif lebih singkat dibanding ternak penghasil daging lainya.

Tahun 2006 kontribusi ayam broiler dalam penyediaan daging di Indonesia berdasarkan angka-angka besar 60,73\% (Balitbang. 2006). Perkembangan ayam broiler saat ini semakin bertambah seiring dengan meningkatnya penghasilan dan kesadaran penduduk akan pentingnya protein hewani. Hasil penelitian Satiawan (2006) menunjukkan bahwa rata-rata laju konsumsi protein antara tahu 1999-2004 sebesar 3,34\% pertahun daan laju kebutuhan protein sebesar o,20\% pertahun.

Bakso adalah jenis makanan yang berupa bola-bola yang terbuat dari daging dan tepung. Makanan ini biasanya disajikan dengan kuah dan mie, bahan-bahan yang dibutuhkan dalam pembuatan bakso adalah daging, bahan perekat, bumbu dan es batu/air es (Singgih, 2000). Biasanya jenis bakso di masyarakat pada umumnya diikuti dengan nama jenis bahan seperti bakso ayam, bakso ikan, bakso sapi.

Bakso merupakan produk emulsi yang memerlukan bahan tambahan dalam proses pembuatanya. Bahan-bahan yang ditambahkan dalam proses pembuatan bakso akan menentukan kualitas bakso yang dihasilkan. Salah satu bahan yang ditambahkan dalam proses pembuatan bakso adalah bahan pengenyal. Penambahan bahan pengenyal pada bakso biasanya menggunakan bahan kimia anorganik yang jika digunakan dalam jumlah besar dapat menimbulkan efek samping. Oleh karena itu dibutuhkan bahan pengenyal alami dalam proses pembuatan bakso. Bahan pengenyal alami yang dapat digunakan adalah putih telur, keragenan, dan agar-agar.

Putih telur merupakan bahan pengikat yang umum digunakan dalam pembuatan bakso, putih telur yang terkandung dalam telur sekitar 56-61 dan dibentuk dari sebagian besar air (90\%) dan protein $(10 \%)$. Putih telur mengandung vitamin riboflavin, niasin, biotin, dan mineral seperti magnesium dan potasium. Putih telur banyak digunakan dalam aplikasi pangan karena sifat-sifat fungsionalnya yang sangat baik.

Agar-agar merupakan campuran polisakarida yang diekstansi dari dinding sel ganggang merah (Rodophyta), khususnya genus Gracilaria dan Gelidium, agar-agar merupakan salah satu hidrokoloid yang memiliki manfaat dan agar-agar juga memiliki fungsi utama sebagai bahan pangan penstabil, pegemulsi, pengental, pengisi, pembuat gel dan lain-lain.

Keragenan berasal dari rumput laut yang mengandung protein. Keragenan dapat menyerap air sehingga menghasilkan tekstur yang kompak, dan dapat meningkatkan daya ikat air. Keragenan dapat juga diaplikasikan pada berbagai produk sebagai pengontrol kadar air (Keton, 2001).

Berdasarkan hal di atas, maka dilakukan penelitian yang berjudul Kandungan Protein dan Kadar Air Bakso Daging Ayam Broiler Pada Penambahan Bahan Pengenyal yang Berbeda. 


\section{Metode Penelitian}

Penelitian ini dilaksanakan pada bulan Juli Tahun 2018, di Laboratorium Fakultas Pertanian, Peternakan, dan Perikanan Universitas Muhammadiyah Parerpare dan dilanjutkan Analisis Kadar Protein dan Kadar Air di Laboratorium Kimia Makanan Ternak, Fakultas Peternakan Universitas Hasanuddin Makassar.

\section{Alat dan Bahan}

Alat-alat yang digunakan adalah pisau, blender, 128ontr, sendok, kompor, pengukus, dan 128ontrol klip, label, penyaring, piring, dan baskom.

Bahan yang digunakan adalah daging ayam broiler, air, penyedap rasa, bawang putih, merica, garam, putih telur, karagenan, agar-agar, 128ontro dan es batu

Rancangan percobaan yang digunakan dalam penelitian ini adalah Rancangan Acak Lengkap (RAL) dengan 4 perlakuan dan 3 ulangan. Perlakuan yang diterapkan adalah:

T0 = Bakso ayam tanpa penambahan pengenyal (128ontrol)

T1 = Bakso dengan penambahan pengenyal putih telur

T2 = bakso dengan penambahan pengenyal karagenan

T3 = Bakso dengan penambahn pengenyal agar-agar

Data yang diperoleh dari panelitian ini dihitung dengan menggunakan Rancangan Acak Lengkap (RAL) menurut Gazpersz (1991), dengan bantuan program SPSS Versi 16.0 For Windows.

\section{Hasil dan Pembahasan}

\section{Kandungan Protein Kasar}

Hasil analisis kandungan protein kasar (\%) bakso daging ayam broiler pada penambahan bahan pengenyal yang berbeda dapat dilihat pada tabel 1 .

\section{Tabel 1. Rata-Rata Kandungan Protein Kasar Bakso Daging Ayam Broiler pada} Penambahan Bahan Pengenyal yang Berbeda.

\begin{tabular}{|l|c|c|c|c|}
\hline $\begin{array}{c}\text { Perlakuan } \\
\text { (Bahan } \\
\text { pengenyal) }\end{array}$ & $\mathbf{U}_{\mathbf{1}}$ & $\mathbf{U}_{\mathbf{2}}$ & $\mathbf{U}_{\mathbf{3}}$ & Rata-rata \\
\hline $\mathrm{T}_{0}$ ( Kontrol) & 6,06 & 6,89 & 6,61 & $6,52^{\mathrm{b}}$ \\
\hline $\mathrm{T}_{1}$ ( Putih telur) & 6,08 & 6,45 & 6,46 & $6,33^{\mathrm{b}}$ \\
\hline $\mathrm{T}_{2}$ (Karagenan) & 6,64 & 6,73 & 6,03 & $6,46^{\mathrm{b}}$ \\
\hline $\mathrm{T}_{3}$ ( Agar-agar) & 4,01 & 4,17 & 4,29 & $4,15^{\mathrm{a}}$ \\
\hline
\end{tabular}

Keterangan: Superskrip yang berbeda pada kolom yang sama menunjukkan berpengaruh sangat nyata $(\mathrm{p}<0,01)$.

Hasil uji analisis menunjukkan bahwa kandungan protei kasar bakso daging ayam broiler pada penambahan pengenyal yang berbeda disajikan pada tabel 2 adalah masingmasing 6,52\%, 6,33\%, 6,46\%, 4,15\% untuk perlakuan $\mathrm{T}_{0}, \mathrm{~T}_{1}, \mathrm{~T}_{2}, \mathrm{~T}_{3}$. 


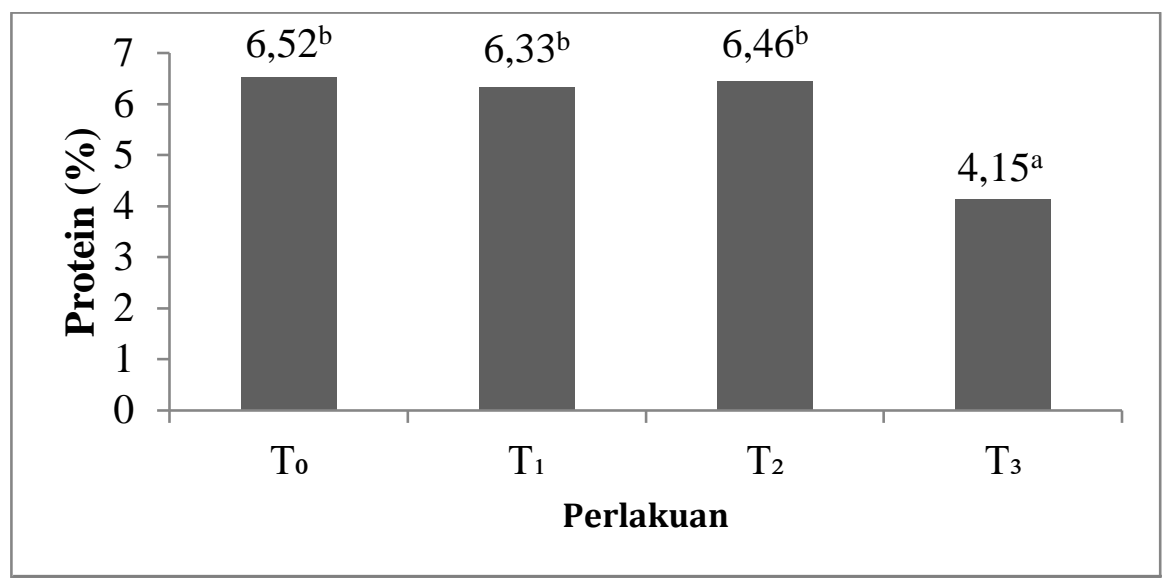

\section{Gambar 1. Hasil Uji Analisis Kandungan Protei Kasar Bakso Daging Ayam Broiler pada Penambahan Pengenyal}

Berdasarkan analisis ragam menunjukkan bahwa perlakuan penambahan bahan pengenyal yang berbeda berpengaruh sangat nyata $(P 0,01)$ terhadap kandungan protein, setelah dilanjutkan dengan uji duncan diketahui bahwa perlakuan $\mathrm{T}_{3}$ berbeda nyata dengan $\mathrm{T}_{0}, \mathrm{~T}_{1}$ dan $\mathrm{T}_{2}$ begitu juga $\mathrm{T}_{1}$ tidak berbeda nyata dengan $\mathrm{T}_{0}$, dan $\mathrm{T}_{2}$ tetap berbeda nyata dengan $\mathrm{T}_{3}$.

Hasil analisis ragam menunjukkan bahwa kandungan protein kasar bakso dengan pengenyal yang berbeda, berpengaruh sangat nyata $(\mathrm{P}<0,01)$ Terhadap kandungan protein, tetapi setelah dilanjutkan dengan uji duncan diketahui terdapat perlakuan tidak berbeda nyata antara kontrol $\mathrm{T}_{0}(6,52 \%)$, dengan perlakuan $\mathrm{T}_{2}(6,46 \%)$ dan $\mathrm{T}_{1}(6,33 \%)$, tetapi berbeda nyata dengan $\mathrm{T}_{3}(4,15 \%)$, Dikatakan tidak berbeda nyata pada pada perlakuan $\mathrm{T}_{0}$, $\mathrm{T}_{1}$, dan $\mathrm{T}_{2}$ karena angka dari perlakuan $\mathrm{T}_{0}, \mathrm{~T}_{1}$, dan $\mathrm{T}_{2}$ terletak pada kolom A sehingga dikatakan tidak berbeda nyata dan nilai dari $\mathrm{T}_{3}$ terletak pada kolom sehingga dikatakan berbeda nyata terhadap $\mathrm{T}_{0}, \mathrm{~T}_{1}$, dan $\mathrm{T}_{3}$. Rata-rata kandungan protein yang diperoleh yaitu $\mathrm{T}_{0}(6,52 \%), \mathrm{T}_{1}(6,33 \%), \mathrm{T}_{2}(6,46 \%)$, dan $\mathrm{T}_{3}(4,15 \%)$.

Berdasarkan rata-rata kandungan protein bakso pada perlakuan kontrol atau $\mathrm{T}_{0}$ merupakan perlakuan yang tertinggi yaitu $6,52 \%$ kandungan menurun pada perlakuan $\mathrm{T}_{3}$ 4,15, $\mathrm{T}_{2}$ 6,46\%, dan $\mathrm{T}_{1}$ 6,46.

Pada perlakuan $\mathrm{T}_{0}$ atau bakso tanpa penambahan bahan pengenyal mengalami kenaikan protein dimana protein $\mathrm{T}_{0}(6,52 \%)$, tingginya protein pada $\mathrm{T}_{0}$ disebabkan karna kandungan pada daging ayam memiliki kandunga protein yang cukup tinggi, dimana kandungan protein pada ayam adalah $18,2 \%$ hal ini sesuai pendapat oleh Kristanto (2005) yang mengatakan bahwa kandungan protein pada ayam adalah 18,2\%.

Pada perlakuan $\mathrm{T}_{1}$ atau bakso dengan penambahan bahan pengenyal mengalami penurunan protein diduga karna telur yang digunakan tidak berkualitas baik dimana telur yang digunakan merupakan telur yang lama sehingga kandungan proteinnya rusak, kandugan protein yang rusak tidak akan bisa membentuk buih secara optimal sesuai pendapat dari Rizal (2006) bahwa lama penyimpanan telur maka telur akan kehilangan gas $\mathrm{C}_{2} \mathrm{O}$ pada telur, gas $\mathrm{C}_{2} \mathrm{O}$ yang hilang akan mengakibatkan pengikat cairan putih telur menjadi rusak dan akan menurunkan kualitas telur, menurut Silverside and Scoot (2000) kualitas putih telur yang rusak akan menyebabkan kerusakan protein dan daya guna putih telur tidak lagi optimal, beserta protein yang telah rusak tidak akan bisa membentuk buih secara optimal. Pada perlakuan $\mathrm{T}_{2}$ atau bakso dengan penambahan bahan pengenyal karagenan mengalami kenaikan walau kenaikan protein hanya berbanding sedikit dari $\mathrm{T}_{1}$, 
kenaikan protein pada $\mathrm{T}_{2}$ bahan pengenyal karagenan disebabkan karena pada bahan pengenyal karagenan memiliki kandungan protein sebanyak 5-15\% (Ahmadi dkk, 2007).

Sebagian besar karagenan mengandung natrium, magnesium, dan kalsium yang dapat terikat pada gugus ester sulfat dari galaktosa dan kopolimer 3,6-anhydro-galaktosa. (Nehen,1987).

Pada perlakuan $\mathrm{T}_{3}$ atau bakso dengan penambahan bahan pengeyal agar-agar mengalami penurunan pada protein, penurunan protein pada bakso dengan pengenyal agar-agar disebabkan karena rendahnya jumlah protein yang dikandung dalam agar-agar yaitu $0,2 \%$. Hal ini sesuai dengan pendapat Yenrina dkk (2011) bahwa kandungan protein pada agar-agar sebanyak 0,5\%. Agar-agar juga memiliki serat yang tinggi dimana serat pada agar-agar sebanyak 10,51\% sesuai menurut Gufran (2010) bahwa kandungan serat pada agar-agar sangat tinggi yaitu mengandung serat sebanyak 10,51\%.

\section{Kandungan Kadar Air}

Hasil analisis kadar air (\%) bakso dengan pengenyal yang berbeda dapat dilihat pada Tabel2.

Tabel 2. Rata-rata Kandungan Kadar Air Bakso dengan Pengenyal yang Berbeda

\begin{tabular}{|l|c|c|c|c|}
\hline $\begin{array}{l}\text { Perlakuan } \\
\text { Bahan pengenyal }\end{array}$ & $\mathbf{U}_{\mathbf{1}}$ & $\mathbf{U}_{\mathbf{2}}$ & $\mathbf{U}_{\mathbf{3}}$ & Rata-rata \\
\hline $\mathrm{T}_{0}$ (Kontrol) & 63,28 & 62,76 & 63,12 & $63,05^{\mathrm{ab}}$ \\
\hline $\mathrm{T}_{1}$ (Putih telur ) & 63,60 & 63,12 & 63,35 & $63,35^{\mathrm{b}}$ \\
\hline $\mathrm{T}_{2}$ (Karagenan ) & 62,66 & 61,95 & 62,71 & $62,44^{\mathrm{a}}$ \\
\hline $\mathrm{T}_{3}$ (Agar-agar) & 62,37 & 62,38 & 63,04 & $63,05^{\mathrm{a}}$ \\
\hline
\end{tabular}

Keterangan: Superskrip yang berbeda pada kolom yang sama menunjukkan berpengaruh nyata $(0,05)$.

Hasil uji analisis menunjukkan bahwa kandungan kadar air bakso dengan pengenyal yang berbeda disajikan pada tabel 3 adalah masing-masing 63,05\%, 63,35\%, 62,44\%, $63,05 \%$ untuk perlakuan $\mathrm{T}_{0}, \mathrm{~T}_{1}, \mathrm{~T}_{2}, \mathrm{~T}_{3}$.

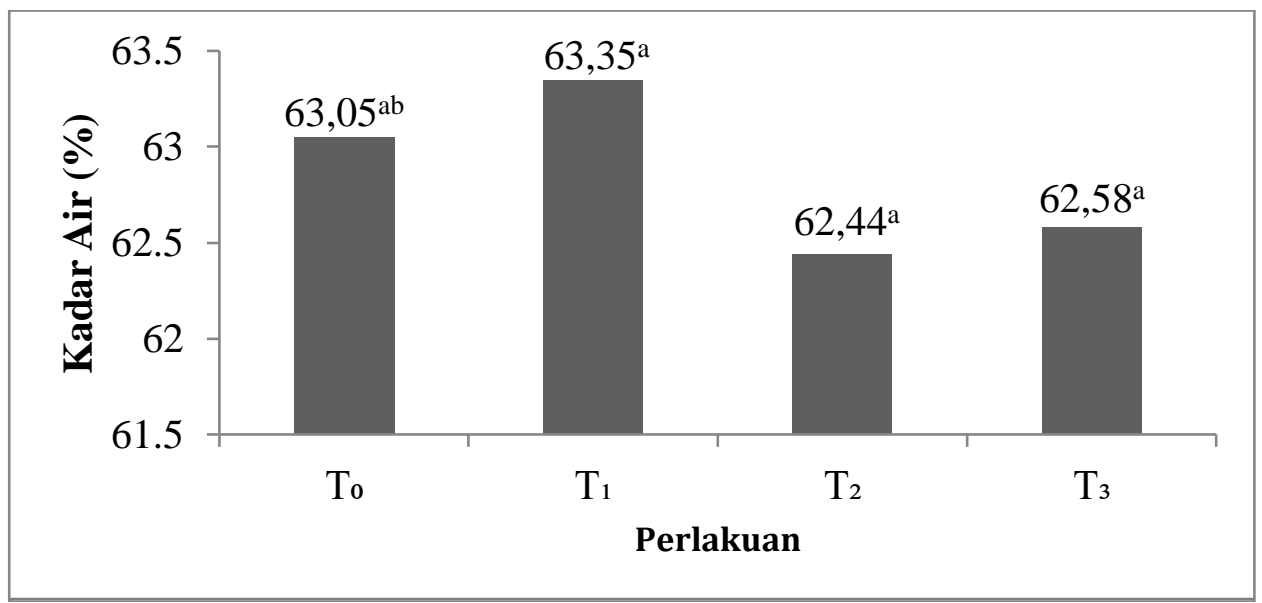

\section{Gambar 2. Hasil Uji Analisis Kandungan Kadar Air Bakso dengan Pengenyal yang Berbeda}


Berdasarkan analisis ragam menunjukkan bahwa perlakuan penambahan bahan pengenyal yang berbeda berpengaruh nyata $(\mathrm{P}<0,5)$ terhadap kandungan kadar air, setelah dilanjutkan dengan uji duncan diketahui bahwa perlakuan $\mathrm{T}_{2}$, tidak berbeda nyata dengan $\mathrm{T}_{0}, \mathrm{~T}_{3}$, Tetapi berbeda nyata dengan $\mathrm{T}_{1}$.

Hasil analisis ragam menunjukkan bahwa kandungan kadar air bakso dengan penambahan bahan pengenyal yang berbeda berpengaruh nyata $(\mathrm{P}<0,05)$ terhadap kandungan kadar air bakso. Jika dilihat dari persentase penurunan kandungan kadar air (\%) bakso dengan penambahan pengenyal yang berbeda yang dimana yang cukup baik adalah yang terendah ke tertinggi, yang terendah adalah $\mathrm{T}_{2}(62,44 \%), \mathrm{T}_{3}(62,58 \%)$, $\mathrm{T}_{0}(63,05 \%)$, dan yang tertinggi adalah $\mathrm{T}_{1}(63,35 \%)$.

Gambar 2 menunjukkan kandungan kadar air bakso dengan penambahan bahan pengenyal yang berbeda, yang terendah terdapat pada perlakuan $\mathrm{T}_{2}(62,44 \%)$ dimana $\mathrm{T}_{2}$ ini menggunakan pengenyal karagenan, disusul dengan perlakuan $\mathrm{T}_{3}(62,58 \%)$ dimana $\mathrm{T}_{3}$ ini menggunakan pengenyal agar-agar. Dengan adanya penambahan pengenyal pada bakso kadar air bakso menurun dari standar kadar air bakso sekitar $70 \%$ menjadi $62.44 \%$ sesuai menurut dari SNI, 1995.

Pada perlakuan $\mathrm{T}_{0}$ atau kontrol kandungan kadar air bakso sebanyak 63,05\%, kadar air bakso pada $\mathrm{T}_{0}$ masih dibawah standar SNI dimana kadar air bakso sebanyak $70 \%$. Berdasarkan Standar Nasional indonesia bahwa kandungan kadar air yang harus di milki adalah tidak lebih dari 70\%

Pada perlakuan $\mathrm{T}_{1}$ atau bahan pengenyal putih telur yang terdapat kenaikan kadar air pada perlakuan $\mathrm{T}_{1}(63,35 \%)$ disebabkan karna adanya prngaruh dari sifat telur sebagai sumber protein yang dapat mengikat air sesuai dengan pendapat dari Pederson (1971). yang mengatakan meningkatnya kadar air disebabkan oleh sifat telur sebagai sumber protein yang dapat mengikat, protein telur tersusun dari komponen-komponen asam-asam amino yang mempunyai cabang dengan muatan proton dan elektron. Hal ini menyebabkan tarik-menarik dengan molekul yang bersifat polar.

Pada perlakuan $\mathrm{T}_{2}$ atau penambahan bahan pengenyal karagenan mengalami penurunan kadar air $(62,44 \%)$, penurunan kadar pada perlakuan $\mathrm{T}_{2}$ disebabkan karna pada penggunaan tepung tapioka dan karagenan memiliki sifat mengikat air lebih.

Penurunan kadar air pada karegenan juga disebabkan karena kadar air pada bakso memiliki ikatan dengan kadar protein dimana jika kandungan kadar air semakin meningkat maka kandungan protein pada bakso semakin menurun begitu pun sebaliknya jika kandungan kadar air menurun maka kandungan protein makso akan semakin meningkat, hal ini sesuai dengan pendapat Pramuditya, dkk (2014) yang mengatakan menurunya kadar air bakso maka kandungaan protein pada bakso akan semakin meningkat dan begitupun sebaliknya.

Pada perlakuan $\mathrm{T}_{3}$ atau penambahan bahan pengenyal agar-agar mengalami penurunan kadar air $(62,58)$ penurunan kadar air pada Perlakuan $\mathrm{T}_{3}$ disebabkan karna pada penggunaan tepung tapioka dan agar-agar yang memiliki sifat mengikat air lebih banyak (Railia, 2010). Ditambakan pula oleh Winarno (2002) yang menyatakan bahwa kandungan kadar air pada bakso dapat dipengaharui oleh senyawa kimia, suhu, konsistrensi dan interaksi dengan komponen penyusun makanan seperti protein, lemak, vitamin, asam-asam lemak bebas, dan komponen lainya. Selain itu, menurut Manullang $d k k$ (1995) yang mengataka penurunan kadar air terjadi mekanisme interaksi pati dan protein sehingga air tidak dapat di ikat sempurna karena ikatan hidrogen yang seharusnya mengikat air telah untuk interaksi pati dan protein.

Adanya penurunan kadar air bakso maka daya simpan bakso akan semakin lama dan bakso tidak akan mudah rusak karan semakin tinggi kadar air pada bakso maka semakin menurun lama penyimpanannya dan begitu sebaliknya semakin rendah kadar air bakso maka daya simpan bakso akan semakin lama sesuai pendapat Winarno et al., (1997) 
yang mengatakan semakin rendah kadar air, semakin lambat pertumbuhan mikrorganisme sehingga bahan pangan dapat bertahan lama. Sebaliknya semkin tinggi kadar air semakin cepat mikrorganisme berkembangbiak sehingga proses pembusukan akan berlangsung semakin cepat.

\section{Kesimpulan}

Berdasarkan hasil dan pembahasan maka dapat disimpulkan bahwa perlakuan penambahan bahan pengenyal yang berbeda dapat mempengaharui kandungan kadar air dan kadar protein. Adapun perlakuan yang terbaik adalah pada perlakuan $\mathrm{T}_{2}$ (Karagenan) dimana terkandung kadar air $62,44 \%$ dan kadar protein $6,46 \%$.

\section{Referensi}

Ahmadi, K., A. Afrila \& W.I. Adhi. (2007). Pengaruh jenis daging dan tingkat penambahan tepung tapioka yang berbeda terhadap kualitas bakso. Buana Sains, 7 (2), 139-144.

Balitbang. (2006). Pengaruh Penguunaan Ampas Kecap Dalam Ransum Sebagai Subtitusi Bungkil Kedelai Terhadap Konsumsi Pakan, Pertambahan Bobot Badan dan Konfersi Pakan Ayam Pedaging Periode Grower. Diakses pada tanggal 27 April 2018.

DKBM. (2005). Pengaruh Tepung Tahu Sebagai Bahan Pensubtitusi Daging Sapi Terhadap Kadar Protein dan Daya Terima Bakso. Diakses pada tanggal 27 April 2018.

Fadillah et. al., (2007). Kandungan gizi daging broiler. Diakses pada tanggal 27 April 2018.

Gufran. (2010). Pengaruh Rasio Tapioka Dengan Rumput Laut Gracillaria Sp. Terhadap karakteristik Sosis Ikan Leniuru. Universitas Udayana. Diakses pada tanggal 23 Agustus 2018.

Keeton, J.T. (2001). Formed and Emulsion Product Dalam; A. R. Shams (Ed), Poultry Meat Processing, CRC. Press, Boca Raton. Diakses pada tanggal 12 Oktober 2018.

Kristanto. A., (2005). Analisis dan Desain Sistem Informasi. Graha Ilmu. Yogyakarta.

Manullang M, Theresia K, Hari E. (1995). Pengaruh Konsentrasi Tepung Tapioka dan Sodium Tripolifosfat terhadap Mutu dan Daya Awet Kamaboko Ikan Pari Kelapa (Trygon Sephen). Bul Tek dan Industri Pangan, 6 (2).

Nehen, I. K. (1987). Study Kelayakan Usaha Budidaya Rumput Laut di Daerah Bali. Universitas Udayana. Denpasar.

Pederson, C.F., 1971. Microbiology of Food Fermentation. Connecticut. A VI Publishing, Westport

Peni S dan Rukmiasih. (2000). Meningkatkan Produksi Daging Unggas. Penebar Swadaya. Jakarta.

Pramuditya, G; S.S. Yuwono. (2014). Penentuan Atribut Mutu Tekstur Bakso Sebagai Syarat Tambahan Dalam SNI dan Pengaruh Lama Pemanasan 34 Terhadap Tekstur Bakso. Fakultas Teknologi Pangan. Universitas Brawijaya Malang. 
Priyatno. (2003). Pengaruh Penguunaan Ampas Kecap Dalam Ransum Sebagai Subtitusi Bungkil Kedelai Terhadap Konsumsi Pakan, Pertambahan Bobot Badan dan Konfersi Pakan Ayam Pedaging Periode Grower. Diakses pada tanggal 27 April 2018.

Rizal, Y. (2006). Ilmu Nutrisi Unggas. Andalas University Press, Padang.

Satiawan. (2006). Pengaruh Penguunaan Ampas Kecap Dalam Ransum Sebagai Subtitusi Bungkil Kedelai Terhadap Konsumsi Pakan, Pertambahan Bobot Badan dan Konfersi Pakan Ayam Pedaging Periode Grower. Diakses pada tanggal 27 April 2018.

Silverside, F.G. and T.A. Scott. (2000). The Relationships Among Measure of Egg Albumen Height, Ph And Whipping Volume. J. Poultry Sci. 83:1619-11623.

Singgih, Wibowo. (2000). Pembuatan Bakso Ikan dan Bakso Daging. Penebar Swadaya. Jakarta. diakses pada tanggal 01 Mei 2018.

SNI. (1995). Standart Nasional Indonesia 01.-3818 tentang bakso daging Sapi. Sudarmadji, S., 1996. Prosedur Analisa untuk Bahan Makanan dan Pertanian. Penerbit Liberty, Yogyakarta diakses pada tanggal 01 Mei 2018.

Winamo, F.G. 1997. Kimia Pangan dan Gizi. PT. Gedia. Jakarta (Di Akses pada tanggal 02 Mei 2018).

Winarno, FG. (2002). Kimia Pangan dan Gizi. Gramedia. Jakarta.

Yenrina, R., Yuliana., \& Dini, R. (2011). Metode Analisis Bahan Pangan. Padang. Fakultas Teknologi Pertanian, Universitas Andalas.

\begin{tabular}{|l|l|}
\hline Rusli & $\begin{array}{l}\text { Program Studi Peternakan, Fakultas Pertanian, Peternakan dan } \\
\text { Perikanan Universitas Muhammadiyah Parepare } \\
\text { E-mail: } \text { ruslipeternakan@gmail.com }\end{array}$ \\
\hline Intan Dwi Novieta & $\begin{array}{l}\text { Program Studi Peternakan, Fakultas Pertanian, Peternakan dan } \\
\text { Perikanan Universitas Muhammadiyah Parepare } \\
\text { E-mail: } \underline{\text { ruslipeternakan@gmail.com }}\end{array}$ \\
\hline Rasbawati & $\begin{array}{l}\text { Program Studi Peternakan, Fakultas Pertanian, Peternakan dan } \\
\text { Perikanan Universitas Muhammadiyah Parepare } \\
\text { E-mail: } \text { ruslipeternakan@gmail.com }\end{array}$ \\
\hline
\end{tabular}

